\title{
INTEGRATION OF KNOWLEDGE MANAGEMENT AND E- LEARNING TECHNOLOGIES IN ACADEMIC INSTITUTIONS
}

\author{
Oloruntoyin Sefiu Taiwo \\ Department of Computer Science and Engineering, Ladoke Akintola University of Technology \\ Ogbomoso, Oyo State, Nigeria. 210271 \\ Email: oloruntoyin86@gmail.com
}

\begin{abstract}
This work investigates the integration of e-Learning systems and knowledge management technology to improve, capture, organize and deliver large amounts of knowledge. First, a model is proposed for the phases of knowledge management. The model is then enhanced with concepts and technology from e-Learning. The model is then used to illustrate real world scenarios that add increasing amounts of knowledge management to an e-Learning environment. The system, AMID promises high interactivity, efficiency and effectiveness of integration of knowledge management and e-learning. In addition, the developed system will enhance technical learning process.
\end{abstract}

Keywords: capture, e-learning, knowledge management, technology

\begin{abstract}
Abstrak: Penelitian ini menyelidiki integrasi sistem e-Learning dan teknologi manajemen pengetahuan untuk meningkatkan, mengambil, mengatur, dan menyampaikan pengetahuan dalam jumlah besar. Pertama, sebuah model diusulkan untuk tahapan manajemen pengetahuan. Model tersebut kemudian disempurnakan dengan konsep dan teknologi dari e-Learning. Model tersebut kemudian digunakan untuk menggambarkan skenario dunia nyata yang menambahkan peningkatan jumlah manajemen pengetahuan ke arah e-Learning. Sistem AMID menjanjikan interaktivitas yang tinggi, efisiensi dan efektivitas integrasi manajemen pengetahuan dan e-learning. Selain itu, sistem yang dikembangkan akan meningkatkan teknis proses pembelajaran.
\end{abstract}

Kata Kunci: e-learning, manajemen pengetahuan, tangkapan, teknologi

\section{Introduction}

Ali et al. (2013) suggested a model that presents certain suggestions to improve the teaching learning process and show how KM provides successful help for the educational consumer in selecting and evaluating e-learning technologies. The model is based on the analysis of KM and e-learning literature and the information of the study; it composed of a range of component and factor that affect integration between knowledge management and e-learning. However it is characterized by dynamic alignment between towards the success of knowledge acquisition in academic institution. In addition the process of active learning is a means to vitalize thoughts of learners besides adding value to the way they adapt to the new learning.

The potential benefit of the model showed in Figure 1, close a strong and significant overlap between knowledge management and e-learning and provides a means to vitalize thoughts of learners besides adding value to the way they adapt to the new learning environment. In reviewing the model in Figure 2, there is a strong overlap that both knowledge management and e-learning are not yet integrated in practice even though both of them possibly have the same objectives and hardly related technologies. 


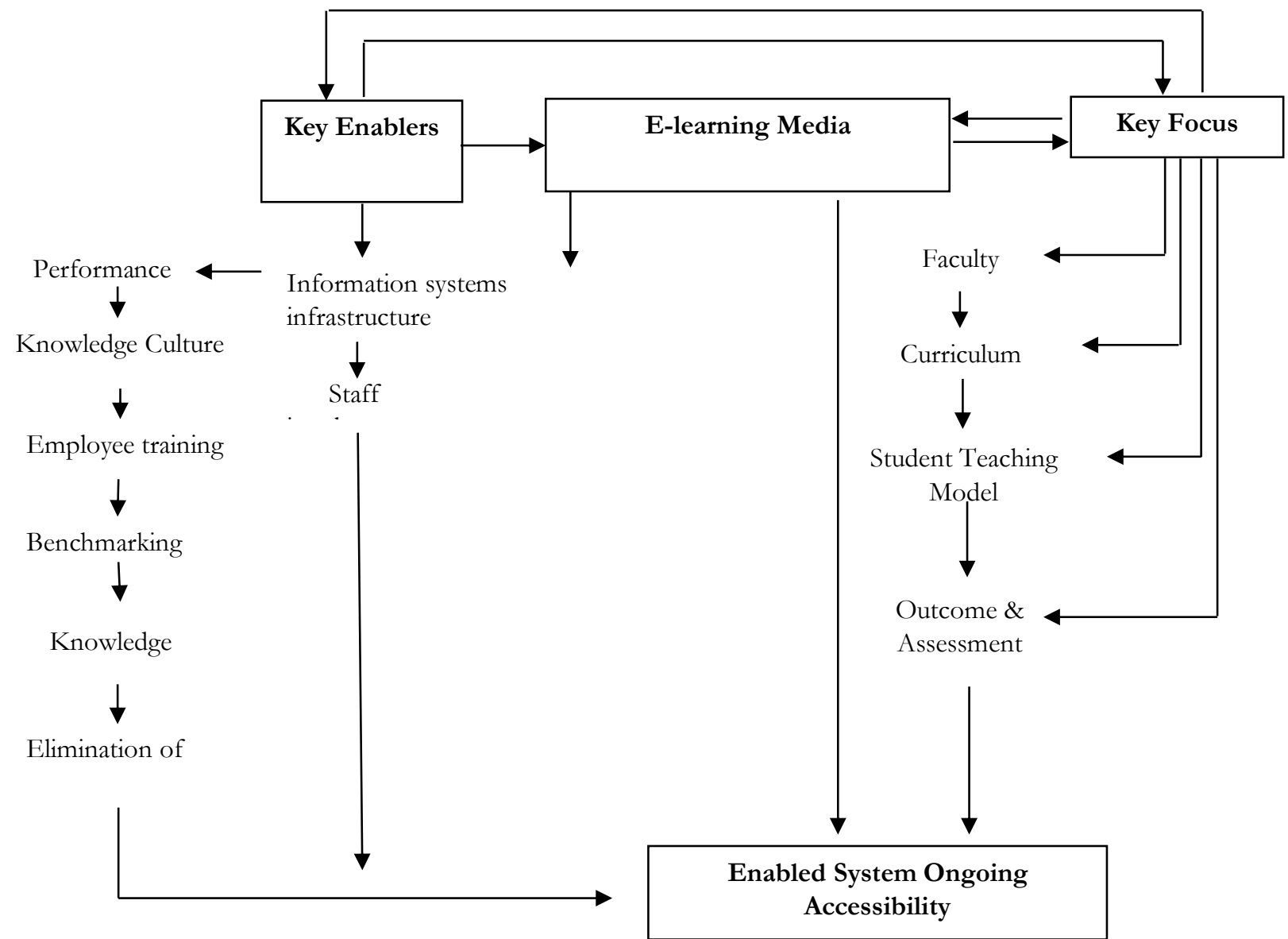

Figure 1. Integration of e-learning \& knowledge management framework (Ali et al., 2013)

\section{The Effects of Integrating Knowledge Management with E-Learning System}

Thair \& Shaima (2014) described that knowledge management technologies provide significant opportunities that enhance e-learning application by extending its reach to wider communities. More so, e-learning system is learning using electronic means: acquisition of knowledge and skill using electronic technology such as computer and internet based courseware and local and wide area network. Similarly, e-learning is as education via internet, intranet/extranets, audio or tape, satellite, TV, and CD ROM. Elearning focuses on the individual acquisition of new knowledge and technological mean to this construction process. Outline the benefits of e-learning as follows:

1. Cost effective: Since E-learning can be done in any geographic location and there are no travel expenses, this type of learning is much less costly than doing learning at a traditional institute.

2. Flexibility: is a major benefit of E-learning. Education is available when and where it is needed. ELearning is flexible and can be customized to meet the individual needs of the learners.

3. Personalized learning: is more focused on the learner and it is more interesting for the learner because it is information that they want to learn.

In addition, he described the concept of $\mathrm{KM}$ is encompassing any processes and practices concerned with the creation, acquisition, capture, sharing and the use of knowledge, skill and expertise. $\mathrm{KM}$ is the discipline that helps spread knowledge of individuals or groups across organization in ways that directly affect performance; KM getting the right information within the right context, person and time for the right business purposes.

Furthermore Thair \& Shaima (2014) proposed a model that integrates E-learning and KM. The purposed model is showed in Figure 2. 


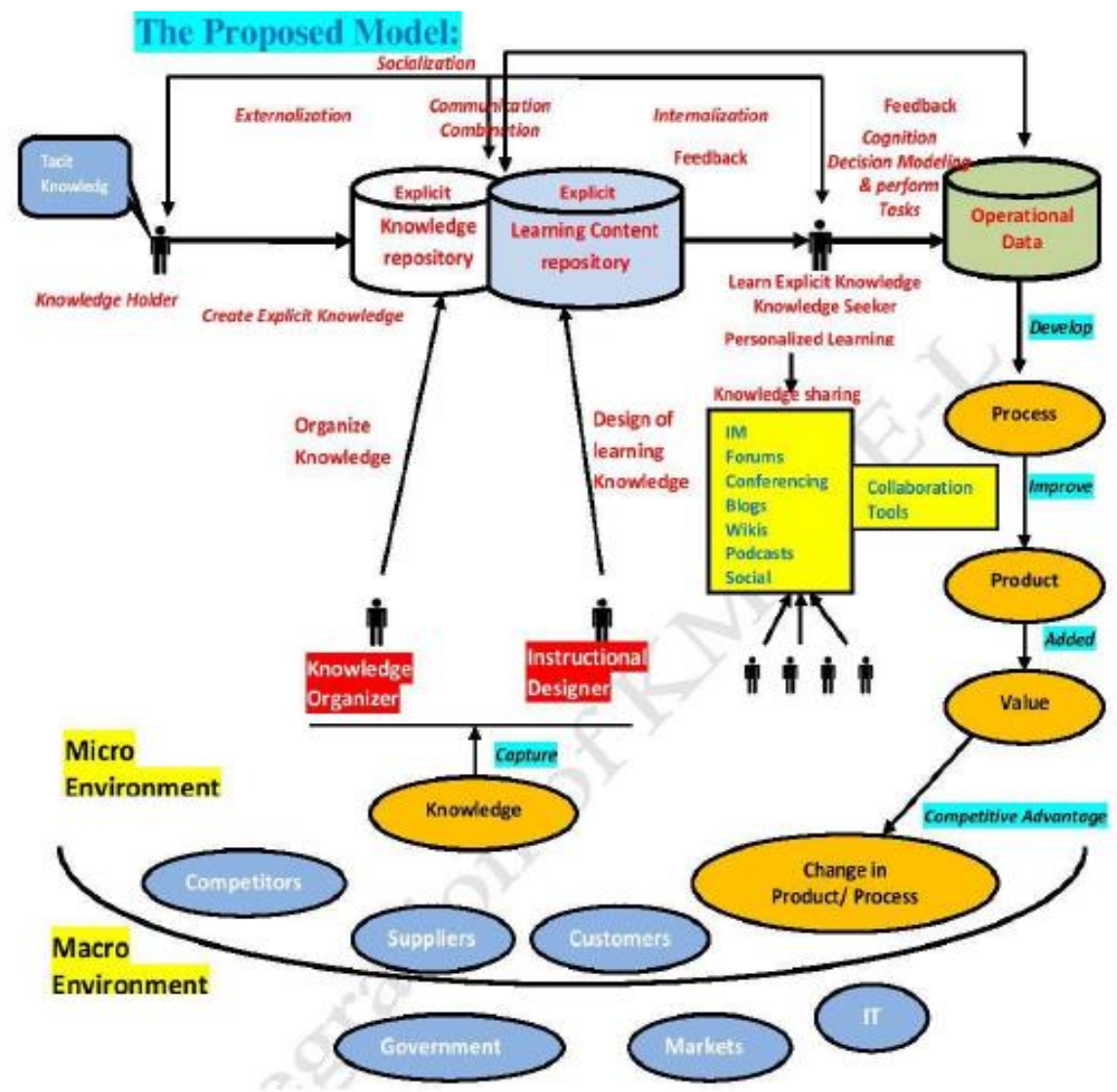

Figure 2. The proposed model (Thair \& Shaima, 2014)

Note on the proposed mode:

1. Knowledge Holder: can either transfer tacit knowledge to a Knowledge Seeker through socialization or create explicit knowledge and store it in a knowledge repository.

2. Knowledge seeker: The Knowledge Seeker learns the explicit knowledge through an online guided learning experience. The Knowledge Seeker then uses the knowledge gained through socialization or internalization to make decisions and perform tasks in the enterprise. The performance of the Knowledge Seeker on these decisions and tasks is measured and returned to the knowledge repository as feedback that can be used to help determine if the skills have been learned and to suggest additional e-Learning experiences.

3. Tacit Knowledge: knowledge that resides in people's mind.

4. Socialization: Transfer tacit knowledge from one person to another person.

5. Externalization: Translate tacit knowledge into explicit knowledge in a repository.

6. Combination: Combine different bodies of explicit knowledge to create new explicit knowledge.

7. Internalization: Extract the explicit knowledge from are repository that is relevant to a particular person's need and deliver it to that person where it is translated into tacit knowledge.

8. Cognition: Apply tacit knowledge to a business problem.

9. Feedback: Assessments provide feedback concerning how well a person has learned and how well they have applied what they learned to a business problem.

10.The Knowledge repository: A Knowledge Repository is a computerized system that systematically captures, organizes and categorizes an organization's knowledge. The repository can be searched and data can be quickly retrieved.

11.A learning content repository: is a store of digital content with an associated set of data management, search and access methods allowing application independent access to the content.

12. Operational data: Information collected during the implementation of a management work processes (transactional data). 
13.Knowledge sharing: knowledge sharing is determined by the following criteria: (a) Articulation: The ability of the user to define what he needs; (b) Awareness: Awareness of the knowledge available; (c) Access: Access to the knowledge; (d) Guidance: Knowledge managers are often considered key in the build-up of a knowledge sharing system. They must help define the areas of expertise of the members of the firm, guide their contributions, assist users, and be responsible for the language used in publications and other communication material. This is so as to avoid an information/knowledge overload; and (e) Completeness: Access to both centrally managed and self-published knowledge.

14.Collaboration tools:

a. Instant Messaging: real time conversation to enhance collaboration in learning event or real time connects for general learning sharing.

b. Discussion forums: focused topic based string of conversations which are storable and searchable.

c. Web- conferencing: real time sharing of presentation and applications over the web and improves connect between experts and learners.

d. Blogs: "author" and instantly publish information, ideas, suggestions, and other content.

e. Wikis: multiple authors collaborate in the creation of a web site, including adding and modifying content co- author and share.

f. Podcast \& videos: online publishing of files and good means of distributing audio and video basedlearning.

g. Social networking: build networks; connect globally and along functional areas of interest.

15. The Instructional Designer: is a person (or software program) who organizes the learning of the knowledge by adding pre-assessments, additional learning aids, and post-assessments.

16.The Knowledge Organizer: is a person (or software program) that relates the created Knowledge to other knowledge in the repository or further refines the created knowledge.

17.The Micro Environment: Factors or elements in an organization's immediate area of operations that affect its performance and decision-making freedom. These factors include competitors, customers, distribution channels, suppliers, and the general public.

18.The Macro Environment: The major external and uncontrollable factors that influence an organization's decision making, and affect its performance and strategies. These factors include the economic factors; demographics; legal, political, and social conditions; technological changes; and natural forces.

The benefit of the model improved capturing and sharing of knowledge management in e-learning system. However, the drop back of the model is; the model will slow in a situation where we have many knowledge seekers on the system because of a single knowledge organizer that the model have.

\section{The Role of Knowledge Management and E-Learning in Professional Development}

Sammour et al. (2008) described knowledge management as techniques that can be used to capture, organizes and deliver knowledge and management system. He discussed the basic concepts of knowledge management and e-learning and how can be integrated and leveraged for effective online education and training. Similarly, he illustrates the role of knowledge management and e-learning in professional development. The role is related to the following:

1. Knowledge creation and acquisition - Knowledge creation and acquisition depend on nurturing people with knowledge - either individually or in teams or in communities of practice - and how knowledge is or can be acquired. The focus is on passive run conscious knowledge acquisition.

2. Knowledge sharing - This takes place when people are genuinely interested in helping one another develop new capacities for action; it is about creating learning processes.

3. Knowledge capture - Knowledge has to be selected, chosen and archived. Here the challenge is capturing tacit knowledge as well as explicit knowledge. It is important to establish processes in order to formalize knowledge preservation. This knowledge has to be captured and stored in databases.

4. Knowledge application - The knowledge created and captured would then need to be applied to achieve competitive advantage.

5. Knowledge evaluation - It must be reviewed to verify that it is relevant and accurate. 
The above-described processes work in a cyclical manner as depicted in Figure 3, taking into consideration that for knowledge creation and acquisition to take place, knowledge needs should be clearly determined in the context of the organizational scope. An inventory of existing knowledge also may exist, which helps in creating and acquiring new knowledge.

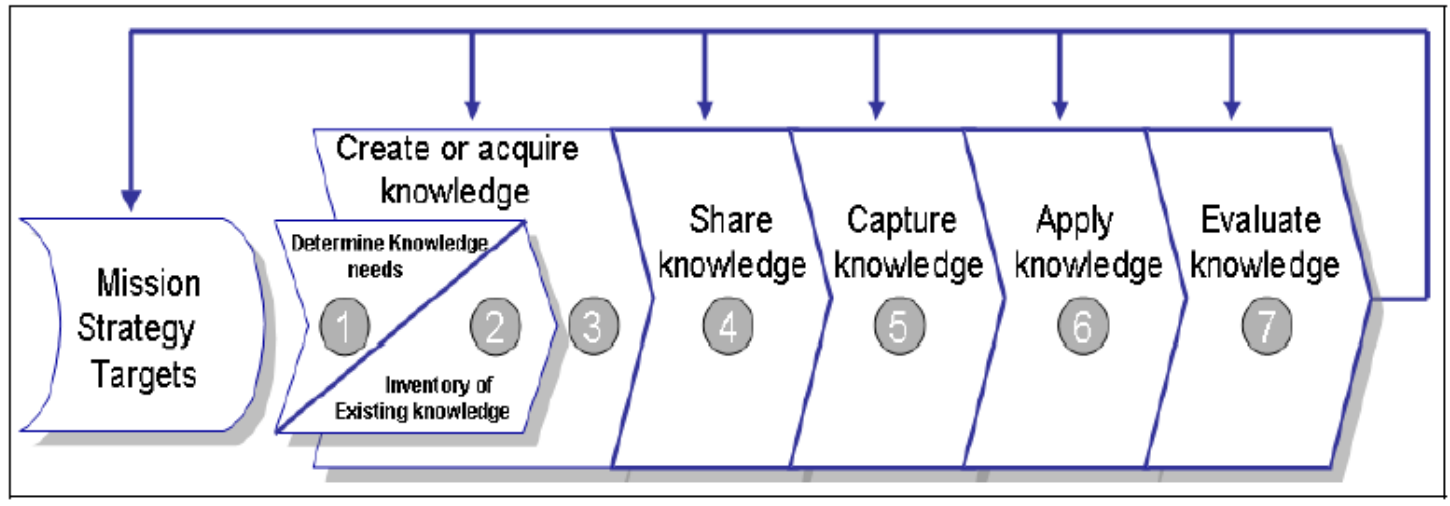

Figure 3. Knowledge management processes (Sammour et al., 2008)

More so, Sammour et al. (2008) integrated the learning cycle within the knowledge management cycle; Figure 4 shows the integrated mode and some of the possible event that take place at each process in the cycle within the organization.

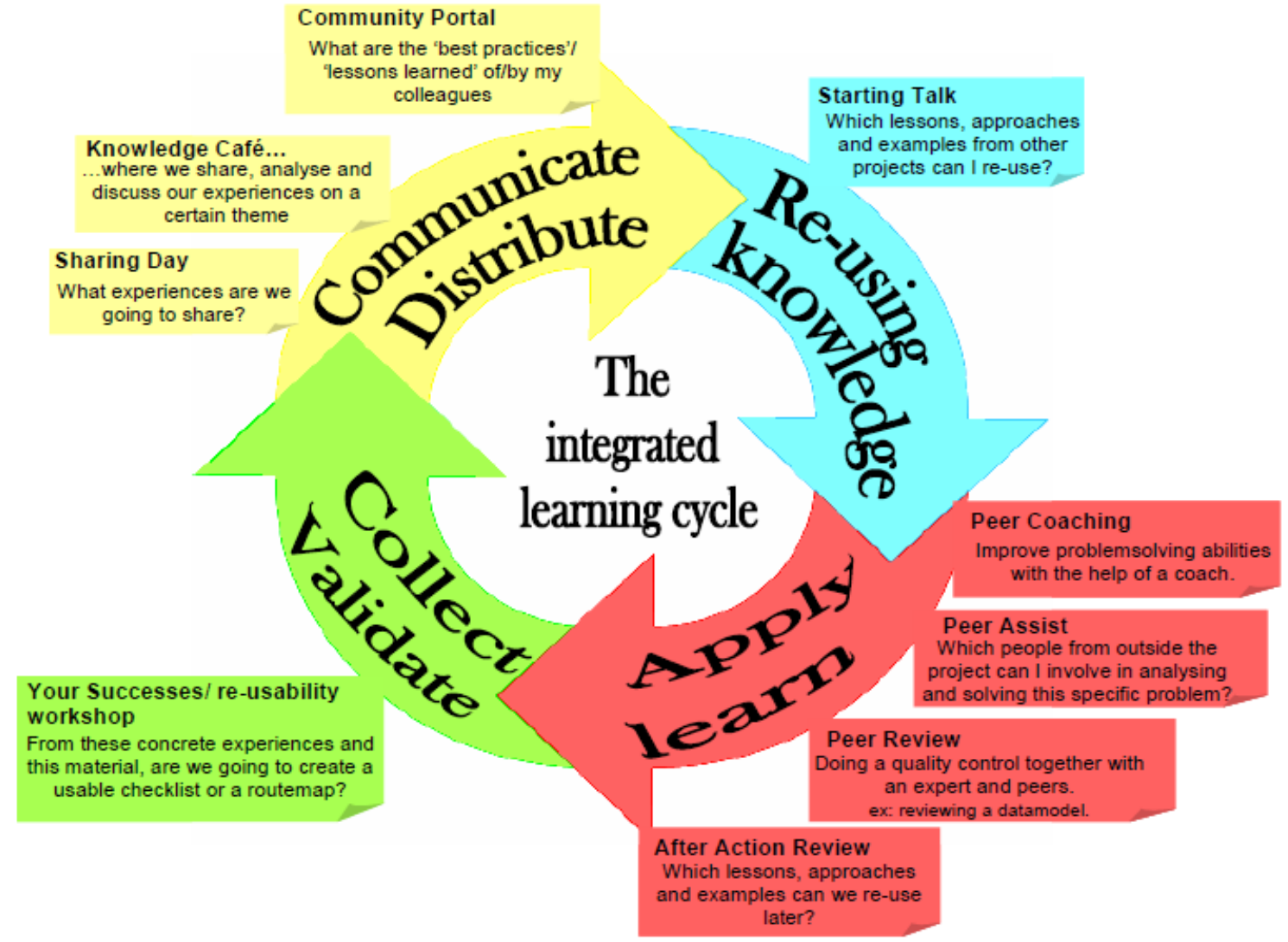

Figure 4. The integrated knowledge management learning cycle (Sammour et al., 2008)

The Strength of the model Sammour et al. (2008) successfully implements the process of KM in context learning: knowledge creation and acquisition, knowledge sharing, knowledge capture, knowledge application knowledge evaluation. The disadvantage of the model is that the knowledge management was not successfully integrated into e-learning system. 


\section{CONCLUSION}

The advent of e-learning has made unlimited source of knowledge available to us all. Researchers have designed many models for integrating knowledge management in to e-learning system. Some are practically implemented while some are not practically implemented. Despite of this various models, researchers are still working for more interactive, efficiency and effective model.

\section{REFERENCES}

Aldrich, Clark. 2000. "The Learning Revolution.” Gartner Symposium, IT XPO 2 Orlando, Florida.

Alrawi, Khalid., Ahmed Alrawi., and Waleed Alrawi. 2012. "How Knowledge Management Adds Critical Value to E-Learning Media." International Journal of Education Administration and Policy Studies 4(3): 78-83. doi: 10.5897/IJEAPS09.097.

Bullinaria, John A. 2005. "IAI: The Roots, Goal and Sub-fields of AI." Available from: https://www.cs.bham.ac.uk/.

Cross, J. 2006. "Informal Learning: Rediscovering The Natural Pathways That Inspire Innovation And Performance.” San Francisco: CA Pfeiffer.

Darrel, Woelk., and Agarwal Shallesh. 2003. "Integration of E-Learning and Knowledge Management" World Conference on Elearning in Corporate Government, Healthcare, and Higher Education 2002: 1035-1042.

Elrehail, Hamzah H., Mahmood A.Trad., and Khaled M. Algraibeh. 2013. “Applying Knowledge Management Oriented Objective into Distance E-learning Process and Strategist.” Management 3(6): 316-322. doi: 10.5923/j.mm.20130306.04.

Fall. 2002. "6.825: Techniques in Artificial Intelligence" A Graduate Level Course of MIT Open Course Mare Develop by Leslie Kaelbling. Lecture 1: 1-6.

Gogos, Roberta. 2013. "A Brief History of E-Learning (Inforgraphic)." Available from: www.efrontlearing.net/blog/2013/08/a-briefhistory-of elearning infographic.html.

Grljeric, Olivera., and Zita Bosnjak. 2011. "Knowledge as Business Opportunity Proceedings of The Management Knowledge and Learning." International Conference 2011, Celje, Slovenia, June 22-24.

Johan, Ismail. 2002. "The Design of An E-Learning System Beyond The Hype." The Internet and Higher Education 4: $329-336$.

Judrups, Janis. 2015. “Analysis of Knowledge Management and E-Learning Integration Models.” Procedia Computer Science 43: 154-162. doi: 10.1016/j.procs.2014.12.021.

Minhong, Wang., and Yang Shephen J.H. 2009. "Knowledge Management \& E-Learning." An International Journal 1(1): 1-5.

Moore, Joi L., Camille Dickson-Deane., and Krista Galyen. 2011. "E-Learning, Online Learning, and Distance Learning environment: Are They The Same?" The Internet and Higher Education 14(2): 129-135.

Nonaka, I., and Takeuchi, H. 1995. "The Knowledge-Creating Company: How Japanese Companies Create The Dynamics of Innovation.” New York: Oxford University Press.

Owayid, Ali Mahdi., Khalid Alrawi., and Khaled Shaalan. 2013. "The Effect of Information Systems Infrastructure and Staff Involvement in the Integration of Knowledge Management and E- Learning Technologies in Academic Institutions.” Cambridge business \& Economics Conference, Cambridge, UK, July 2-3: 1-26.

Prusak, L. 200. “Where did Knowledge Management Come From.” IBM Systems Journal 40(4): 1002-1007.

Sammour, G., Schreurs, J., Al-Zoubi, A.Y., and Vanhoof, K. 2008. "The Role of Knowledge Management and E-Learning in Professional Development." International Journal, Knowledge and Learning 4(5): 465-477.

Thairkhdour., and Shaima Salem. 2004. "The Effects of Integrating Knowledge Management with E-Learning System." Proceeding of 2014 Zone 1 Conference of The American Society for Engineering (ASEE Zone 1): 1-6.

Wild, Rosemary H., Kenneth A. Griggs., and Tanya Downing. 2002. "A Framework for E-Learning as a Tool for Knowledge Management.” Industrial Management \& Data Systems 2(2): 371-380. 